\title{
Social Media Chatbots for Collaborated Engagement Marketing
}

\author{
Ayu Amalia ${ }^{1}$ dan Mohammad Sani Suprayogi ${ }^{2}$ \\ ${ }^{1}$ Universitas Muhammadiyah Yogyakarta, ${ }^{2}$ GDILab \\ Email: ami.khavid@umy.ac.id ${ }^{1 *}$,yogie@gdilab.com ${ }^{2}$ \\ *corresponding author
}

\section{Keywords:}

Engagement Marketing, Social Media, Top of Mind, Collaboration, Chatbot.

\section{Kata Kunci:}

Engagement Marketing, Media Sosial, Top of Mind, Kolaborasi, Chatbot.

\begin{abstract}
Addressing to consumer goods, cover many aspects, some of which are usability, innovation, and preference, when conversation has reached the subject of preferences, brands that occupy top of mind positions will tend to stick to their position in the minds of consumers. A sustainable brand no longer talks about sales and promotions as fundamental aspects. Parallel to this, maintaining customer loyalty that makes the brand in a top of mind position is a top priority. This study discusses the implementation of chatbot in the customer engagement process as part of collaborated engagement marketing, a collaboration between Danone AQUA by utilizing the social media platform, such as Twitter and Facebook, with the ultimate goal is to maintain loyal consumers to increase sales, with gimmicks in the form of additional Go-Pay balances, what can be obtained by AQUA consumers and Go-Jek application users, is done collaboratively by designating convenience stores, namely Indomaret and Alfamart, to become middle-men (sales agents).
\end{abstract}

\begin{abstract}
ABSTRAK
Berbicara tentang consumer goods, akan mencakup banyak aspek, beberapa diantaranya adalah kegunaan, inovasi, hingga preferensi, dan jika perbincangan telah sampai pada perihal preferensi maka merk-merk (brand) yang menduduki posisi top of mind akan cenderung bertahan pada posisinya di benak konsumen. Brand yang telah sustainable tidak lagi membicarakan sales dan promosi sebagai hal yang sangat fundamental. Paralel dengan hal tersebut, mempertahankan loyalitas pelanggan yang menjadikan brand berada pada posisi top of mind, menjadi prioritas utama. Penelitian ini membahas implementasi chatbot dalam proses customer engagement sebagai bagian dari collaborated engagement marketing, merupakan kerjasama antara Danone AQUA dengan memanfaatkan social media platform Twitter dan Facebook, yang tujuan akhirnya adalah mempertahankan konsumen loyal untuk meningkatkan penjualan, dengan gimmick berupa tambahan saldo Go-Pay, yang bisa didapatkan oleh konsumen AQUA sekaligus pengguna aplikasi GoJek, dilakukan secara kolaboratif dengan menunjuk convenience stores, yaitu Indomaret dan Alfamart, untuk menjadi middle-men (agen penjual).
\end{abstract}

Copyright (C) 2019 Channel Jurnal Komunikasi. All right reserved. 


\section{PENDAHULUAN}

Penelitian tentang media sosial, dan Komunikasi dalam platform digital dilakukan, salah satu tujuannya untuk memetakan pola utilisasi media sosial oleh penggunanya, sebagaimana merujuk pada penelitian sebelumnya oleh penulis, Marking Social Issue on Social Media (Case Study of Social Media's Trending Topic that Represents Social Issue in Yogyakarta on Twitter) yang mendeskripsikan hasil temuan penelitian, utilisasi media sosial, khususnya Twitter dengan menggunakan tanda tagar (hashtags) tertentu untuk mengorganisir percakapan (conversation) yang mendorong terjadinya gerakan pengguna media sosial secara kolektif, pembentukan opini publik, mendukung kesuksesan sebuah kampanye (campaign), atau cause, seperti penggunaan tanda tagar \#JogjaOraDidol \#jogjaoradidol yang diinisiasi oleh pengguna media sosial berbasis di Yogyakarta yang prihatin dengan fenomena pembangunan akomodasi wisata masif terjadi di Yogyakarta pada rentang waktu 2014 - 2015, berdampak pada terjadinya sejumlah permasalahan urban yang terjadi di Yogyakarta, seperti berkurangnya lahan untuk fasilitas publik, peningkatan arus lalu lintas akibat gelombang wisatawan yang menetap sementara di Yogyakarta dan mengakibatkan kemacetan. Fenomena permasalahan urban yang disorot dengan memanfaatkan 'percakapan' pada media sosial, khususnya Twitter ini menyuarakan keresahan masyarakat Yogyakarta, pengguna media sosial, secara signifikan, di masa mendatang dapat menjadi pertimbangan bagi pemerintah, maupun pejabat yang berwenang, guna menerbitkan kebijakan yang dapat menjadi solusi atas dampak dari sektor wisata yang berkembang masif agar dapat dikelola sehingga menimbulkan efek positif bagi masyarakat lokal Yogyakarta dan masyarakat wisatawan yang datang ke Yogyakarta. (Amalia \& Suprayogi, 2016).

Bertolak dari penelitian tentang utilisasi media sosial yang pernah dilakukan sebelumnya pada tahun 2015 tersebut diatas, peneliti kemudian mengambil ceruk yang lebih spesifik sebagai bagian dari implementasi fitur media sosial terbaru yaitu chatbot yang difungsikan dalam rangka mendukung pemasaran, yang saat ini bergerak ke arah lebih dinamis, dimana para pemasar tidak lagi menilai konsumen sebagai pihak yang pasif. Hal ini dapat diamati dari seiring kemudahan akses teknologi, membuat konsumen semakin aktif memperkaya dirinya dengan pengetahuan yang terkait dengan industri, bisnis, dan secara spesifik terkait dengan consumer goods.

Kebutuhan hidup sehari-hari konsumen salah satunya dipenuhi dengan adanya industri fast moving consumer goods, yang didistribusikan secara luas oleh peritel moderen, seperti waralaba swalayan (convenience-store chains), supermarket, dan hipermarket - yang mengalami pertumbuhan dua kali lebih cepat (Atsmon \& Magni, 2016; Zipser, Gong, \& Chen, 2016) ${ }^{1}$ dibandingkan peritel tradisional. Pelaku industri consumer-packaged-goods (CPG), disimpulkan oleh hasil survei tersebut, berhasil menavigasi pasar consumer goods secara nasional, dengan beberapa nama perusahaan yang dirujuk sebagai produsen merek yang banyak dikonsumsi oleh konsumen Indonesia, antara lain $P \& G, J o h n s o n \&$ Johnson, L'oreal, Arnott's, dan Danone dari skala multinasional, untuk skala nasional merujuk pada Indofood, Mayora, dan Kalbe. ${ }^{2}$

'Indonesia constitutes 40 percent of Southeast Asia's total population of 664 million people.'

'In 2017, the firm also found that packaged foods, beverages and tobacco products constituted Indonesian consumers' biggest grocery expenditures, accounting for more than a third of their total spending amount throughout 2017.(TheJakartaPost, 2018)

Hasil survei yang dikemukakan The Jakarta Post tersebut menandakan, consumer-packaged-goods (CPG) masih menjadi primadona industri retail di Indonesia, ini sejalan dengan survei dilakukan oleh Nielsen Indonesia, bagian dari The Nielsen Company, US, pada tahun 2018, yang fokus kepada pasar minuman, khususnya minuman dalam kemasan siap minum (ready to drink/RTD). Nielsen Retail Audit ${ }^{4}$ mendapatkan hasil, lebih dari 100 merek minuman RTD baru memasuki pasar minuman kemasan di Indonesia, dan diantaranya, air mineral (mineral water) masih menduduki produk yang paling banyak dikonsumsi oleh konsumen Indonesia, menguasai 33\% dari market share kategori minuman dalam

1 Hasil survei McKinsey company \& Nielsen, dipublikasikan Oktober 2016. (https://www.mckinsey.com/industries/retail/ our-insights/chinese-consumers-revisiting-our-predictions)

2 Perusahaan yang hadir pada 2014 Asia Customer and Channel Management Survey, dilaporkan oleh survei McKinsey company \& Nielsen, dipublikasikan September 2015 (https://www.mckinsey.com/featured-insights/asia-pacific/winning-in-indonesiasconsumer-goods-market)

3 Hasil riset Euromonitor International (Lembaga independen penyedia data strategic market research) dalam Indonesia Conference yang fokus pada dinamika kompetisi pelaku industri fast moving consumer goods bekerjasama dengan The Jakarta Post pada 25 September 2018. (https:/www.thejakartapost.com/adv/2018/09/27/indonesia-to-see-more-fragmented-competition-in-fmcgeuromonitor.html)

4 Hasil survei Nielsen Retail Audit, RTD Beverages, Urban-Nasional, MAT 16 - 18 (https://swa.co.id/swa/my-article/riuhrendah-kompetisi-pelepas-dahaga)

5 Riset Nielsen Beverages Share of Throat merupakan hasil survei dan pengamatan atas perilaku konsumen Indonesia, berdasarkan 18 kategori minuman (in-home and out-of-home consumption), dilakukan dengan wawancara tatap muka dan pendokumentasian, melibatkan 1.150 responden dipilih secara acak dari lima kota besar: DKI Jakarta, Yogyakarta, Surabaya, Medan, Makassar. (https://www.nielsen.com/id/en/insights/news/2018/riuh-rendah-kompetisipelepas-dahaga.html) 
kemasan siap minum, ditampilkan dalam Grafik 1, untuk Beverage Share of Throat, mengindikasikan bahwa air mineral menduduki posisi puncak, dibandingkan produk minuman teh, dengan market share $23 \%$ yang bersaing cukup ketat dengan produk minuman kopi, dengan market share sebesar $21 \%$.

Grafik 1

Sumber: Nielsen Retail Audit Indonesia (2018)

\section{BEVERAGE SHARE OF THROAT}
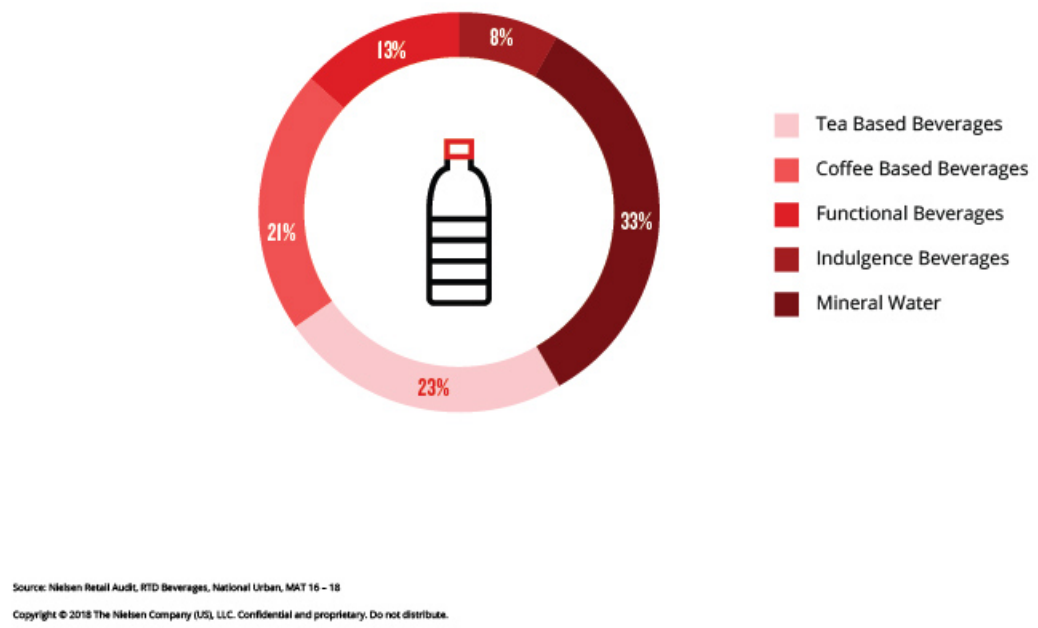

Berbicara tentang consumer goods, mencakup banyak aspek, diantaranya adalah kegunaan, inovasi, hingga preferensi, dan jika perbincangan telah sampai pada perihal preferensi maka merk-merk (brand) yang menduduki posisi leading brands akan cenderung bertahan pada posisinya di benak konsumen. Brand yang telah sustainable tidak lagi membicarakan sales dan promosi sebagai hal yang sangat fundamental. Paralel dengan hal tersebut, mempertahankan loyalitas pelanggan yang menjadikan brand berada pada posisi leading brands, menjadi prioritas utama.

Industri consumer goods mendapat sorotan konstan dari Lembaga Riset ataupun Asosiasi Pemasar, terutama pada upaya pelaku industrinya untuk memimpin pasar berdasarkan beberapa aspek: Sales strategy, pricing, trade investment, dan route-to-market (RTM) performance. (Magni, dkk., 2015). ${ }^{6}$ Consumer goods tidak akan lepas dari upaya pelaku industri consumer goods untuk mempromosikan sekaligus mengantarkan produk consumer goods ke konsumen, maka, hal lain yang perlu dipikirkan oleh pelaku industri consumer goods adalah menginisiasi consumer-awareness atas produknya, pada era digital ini, hubungan antara produsen dan konsumen merupakan hubungan dua arah, keduanya berperan secara aktif dalam interaksi transaksional.

Pemutakhiran teknologi berdampak pada cara produsen consumer goods untuk menjalin interaksi dengan konsumennya, hal ini juga dipengaruhi dengan adanya tren digital berupa user generated content yang memungkinkan konsumen sebagai pengguna teknologi internet dan teknologi digital mengkreasikan konten dengan ciri khas personalnya, dan produsen perlu mengikuti tren ini agar dapat senantiasa terhubung dengan konsumen secara personal, sekaligus dapat mengikuti perubahan tren pemasaran disesuaikan dengan perilaku konsumen yang cenderung dinamis, siklus ini terlebih dahulu ditandai dengan meningkatnya presentasi pengguna internet di Indonesia pada tahun 2017, menurut APJII, sebesar 54,68\% dari total populasi penduduk Indonesia sebanyak 262 juta orang, yaitu 143.26 juta orang Indonesia telah menggunakan teknologi internet mengalami peningkatan dari tahun 2016, sebanyak 132.7 juta jiwa (APJII, 2018). ${ }^{7}$

Lanskap digital konsumen Indonesia pun berubah seiring bertambahnya pemakai perangkat telepon cerdas untuk mengakses internet, sejumlah $44.16 \%{ }^{8} \mathrm{Hal}$ ini diperkuat oleh hasil survei Euromonitor International, dalam skala global,

6 Hasil survei yang dilakukan McKinsey company bekerjasama dengan Nielsen, yang dipublikasikan September 2015. (https://www.nielsen.com/id/en/insights/news/2018/riuh-rendah-kompetisi-pelepas-dahaga.html)

7 Hasil Survei Penetrasi \& Perilaku Pengguna Internet Indonesia tahun 2017 oleh Asosiasi Penyelenggara Jasa Internet Indonesia bekerjasama dengan http://teknopreneur.com (https://web.kominfo.go.id/sites/default/files/Laporan\%20Survei\%20 APJII_2017_v1.3.pdf)

8 Loc. cit. 
Indonesia menduduki peringkat ketiga untuk jumlah mobile-subscribers terbanyak di dunia, setelah India dan Cina. ${ }^{9}$ Social media menjadi platform peringkat kedua yang paling banyak diakses oleh pengguna internet selain platform chat yang menduduki peringkat pertama. ${ }^{10}$ Social media memungkinkan seorang konsumen berkomunikasi dengan sejumlah konsumen lain, mendiskusikan produk yang bisa memenuhi kebutuhannya. Fenomena ini telah mengubah marketplace secara signifikan, secara tradisional, memungkinkan terjadinya komunikasi interaktif produsen dengan konsumen, secara non-tradisional, memungkinkan terjalinnya komunikasi diantara sesama konsumen (Mangold \& Faulds, 2009).

Produsen secara pro aktif menindaklanjuti berkembangnya tren ini, beberapa social media platform dipilih untuk dapat menjangkau sekaligus berinteraksi dengan konsumen sesuai dengan fungsi masing-masing platform. Hasil unggahan di social media menjadi faktor yang berpengaruh cukup signifikan untuk para konsumen memutuskan produk mana yang akan dibeli dan dikonsumsi, dibuktikan dengan hasil survei APJII tahun 2017, terkait dengan 'Pemanfaatan Internet di Bidang Ekonomi', motivasi utama pengguna internet adalah untuk mencari informasi ataupun membandingkan harga, dilakukan oleh sebanyak $45.14 \%$ pengguna internet, sedangkan pemenuhan informasi untuk keperluan membeli produk, merupakan aktivitas yang menduduki posisi ketiga, dilakukan oleh sejumlah $37.82 \%$ pengguna internet, selanjutnya pengguna internet akan melakukan pembelian secara online dari online shop ataupun online marketplace, yang merupakan aktivitas di posisi keempat yang dilakukan oleh konsumen sekaligus 32.19\% pengguna internet. ${ }^{11}$

Kesimpulan dari serangkaian aktivitas tersebut, bahwa konsumen tidak lagi sebagai pengkonsumsi yang pasif, telah menaikkan bargaining position-nya dengan memanfaatkan teknologi internet, memiliki posisi yang setara dengan produsen dalam aktivitas transaksional yang terkait dengan consumer goods, direspon oleh produsen dengan mengintegrasikan beberapa upaya pemasaran strategis sebagai bagian dari customer engagement marketing, dijelaskan oleh Harmelling, dkk (2016) sebagai upaya yang dilakukan oleh korporasi untuk memotivasi, memberdayakan, dan mengukur kontribusi pelanggan guna memenuhi fungsi pemasaran, tidak hanya mencakup transaksi ekonomi yang dijalankan korporasi. Hal tersebut berdampak langsung pada terjadinya customer engagement (Harmeling, Moffett, Arnold, \& Carlson, 2017), yang dijelaskan sebagai upaya sukarela dari konsumen untuk berkontribusi terhadap pemenuhan fungsi pemasaran sebuah korporasi, yang tidak hanya terbatas pada dukungan finansial.

Penelitian yang turut membahas customer engagement, oleh $\mathrm{Xu}$, Weber, dan Buhalis berjudul Gamification in Tourism, dalam jurnal Information and Communication Technologies in Tourism 2014, meng-highlight metode gamification untuk mendukung terjadinya customer engagement, guna menjaga loyalitas konsumen untuk mendukung perkembangan pariwisata, dilakukan oleh Lufthansa dan American Airlines. (Xu, Weber, \& Buhalis, 2013). Penelitian ini membahas customer engagement antara konsumen dan korporasi dengan menggunakan digital platform seperti mobile application dan social media untuk mengimplementasikan elemen-elemen dalam desain game, dan strategi game sebagai bagian dari upaya menjaga keterlibatan konsumen untuk mengintensifikasikan consumer engagement, customer loyalty, brand awaraness, sekaligus optimalisasi user experience, terhadap brand dan korporasi terkait.

\section{METODE PENELITIAN}

Penelitian ini bertujuan untuk mendeskripsikan campaign yang dilakukan sebagai bagian dari Customer Engagement Marketing yang merupakan pemutakhiran dari Integrated Marketing Communication (IMC) di era digital. Customer Engagement Marketing -- didefinisikan sebagai upaya yang disengaja perusahaan untuk memotivasi, memberdayakan, dan mengukur kontribusi pelanggan untuk fungsi pemasaran — menandai perubahan dalam riset pemasaran dan praktik bisnis. (Harmeling, 2017). Penelitian ini dilakukan dengan melakukan analisis atas bagian/part (sequence analysis) dari proses customer engagement marketing yang melibatkan beberapa pihak pelaku industri yang ada di tanah air, yaitu Twitter dan Facebook sebagai penyedia platform media sosial, GDILab. sebagai developer chatbot yang khusus digunakan sebagai auto-responder pada Twitter dan Facebook, Danone Aqua sebagai pemilik brand yang ingin mempertahankan posisinya sebagai brand yang telah menduduki posisi top of mind kategori minuman readyto-drink (RTD) di benak konsumen, paralel dengan convenient store seperti Indomaret dan Alfamart yang bertujuan untuk meningkatkan jumlah penjualan, khususnya untuk minuman ready to drink (RTD), pihak lain yang terlibat dalam collaborated engagement marketing ini adalah pemilik lisensi fintech (financial technology) pada periode penelitian ini dilaksanakan, yaitu 2015, GoJek hendak menginisiasi awareness penggunanya, yaitu pengguna teknologi pembayaran secara digital dengan menggunakan perangkat mobile atas produknya yang dikenal dengan GoPay.

Penelitian ini bertujuan untuk mendeskripsikan praktek collaborated engagement marketing dengan konsumen sebagai pelaku utama, yang prosesnya melibatkan berbagai pihak pelaku industri consumer goods dan pelaku industri digital, dengan memanfaatkan chatbot media sosial. Penelitian ini dilakukan dengan melakukan studi dokumentasi atas konten platform Twitter yang dilakukan melalui pengiriman direct message (DM) ditujukan untuk akun@sehatAQUA, maupun pengiriman pesan melalui fitur messenger yang dimiliki Facebook ditujukan untuk 'Sehat AQUA' Facebook page, pada tahap berikutnya pengguna media sosial akan memperoleh pesan berupa auto-respond dari chatbot yang

9 The Jakarta Post, loc. cit.

10 APJII 2017, loc. cit.

11 APJII 2017, loc. cit. 
diimplementasikan di akun Twitter dan Facebook tersebut.

\section{HASIL DAN ANALISIS \\ Chatbot dan Collaborated Engangement Marketing dalam era User Generated Content}

Teknologi internet yang ada pada masa sekarang memungkinkan berkembangannya situs web yang dapat dikategorikan sebagai Web 5.0, dimana web versi ini memiliki fitur yang bisa "memahami" penggunanya dengan berbekal pada algoritma pemrograman yang dapat memetakan preferensi pengguna ke dalam zona pencarian konten, dari sinilah web juga dapat melakukan navigasi atas pencarian konten yang berguna bagi penggunanya, maupun memberikan rekomendasi. Rekomendasi yang diberikan berdasarkan konten dengan karakteristik yang sesuai dengan preferensi pengguna web, salah satunya dipengaruhi oleh fenomena user-generated-content yang diadposi oleh pengguna web sejak era Web 3.0 yang ditandai dengan beroperasinya interactive web, dimana developer web hanya menyediakan platform sebagai 'wadah' dari konten web yang diciptakan oleh pengguna web itu sendiri, secara masif dikenal dengan beroperasinya media sosial.

Penelitian ini fokus pada peran social media dalam proses terjadinya customer engagement terkait dengan leading brand untuk minuman dalam kemasan siap minum (ready to drink/RTD) yang memimpin market share, dimana leading brand tersebut telah menduduki posisi top of mind di kelasnya. Danone Aqua yang terkenal dengan tagline 'Ada Aqua?' berupaya meningkatkan keterlibatan konsumennya dengan kampanye digital, dilakukan pada social media platform yang mengandalkan fungsi microblogging pada Twitter dan fungsi social networking pada Facebook. Kedua social media platform ini dipilih karena memungkinkan penambahan auto responder berupa chatbot yang dapat melakukan komunikasi interaktif dengan konsumen Aqua, dalam rangka menjaga keberlangsungan proses customer engagement antara produsen dengan konsumen.

Chatbot atau chatterbot merupakan sebutan untuk entitas percakapan buatan yang mensimulasikan percakapan interaktif manusia dengan menggunakan frase yang sering digunakan oleh pengguna internet yang telah dikalkulasi sebelumnya (key pre-calculated user phrases) atau menggunakan sinyal yang berbasis audio maupun teks (auditory or text-based signals). ${ }^{12}$ Chatbot digunakan sebagai auto responder pada layanan konsumen, social networking platform, pengguna layanan pesan instan (instant messaging), bahkan menjadi bagian dari sistem operasi sebagai asistem kecerdasan virtual. ${ }^{13}$

Berbicara tentang customer engagement di era digital ini, maka salah satunya akan menitikberatkan pada aspek user experience, yang dapat diamati dari kemudahan dalam menjangkau brand dan korporasi, sekaligus mempertahankan interaksi antara produsen dan konsumen suatu brand dalam kurun waktu lebih lama. User experience yang berindikasi positif, menjadi salah satu parameter keberhasilan customer engagement dapat diamati sejak berkembangnya media sosial yang dimulai pada era Web 2.0; dijelaskan oleh (Choudhury, 2014) merupakan era read and write web yang menghubungkan antar pengguna internet, yang juga dikenal sebagai social web, kemudian berkembang pada era Web 3.0 merupakan execute web, merupakan wadah untuk kolaborasi antar pengguna internet, dimana web creator hanya menyediakan wadah atau platform saja, sedangkan pengguna internet yang lain, berkontribusi dengan menyediakan konten, yang memungkinkan pengembangan managemen data, men-support akses pada perangkat mobile, bahkan mensimulasikan kreativtas serta inovasi dari para pengguna internet, memfasilitasi terjadinya kolaborasi dalam social web.

Karakter media sosial selain interaktivitas adalah user generated content yang turut menjadi tolok ukur dari keberhasilan customer engagement, dijelaskan oleh Lister sebagai relasi simbiosis dalam budaya media baru yang memberikan kesempatan dan keleluasaan pengguna internet untuk berkontribusi dan berpartisipasi. Teknologi baru, dijelaskan oleh Jenkins (2002) sebagai teknologi yang meruntuhkan pembatas antara konsumsi media dan produksi media, dimana lingkungan digital baru mendorong pengguna media untuk mengembangkan keleluasaan untuk mengarsip, menambahkan catatan, menyesuaikan, dan meresirkulasi produk-produk media. (Lister, Dovey, Giddings, Grant, \& Kelly, 2003).

Media sosial pada akhirnya akan mempermudah penggunanya dengan mengandalkan 'catatan' atau 'jurnal' yang diciptakan dengan melakukan kurasi atas preferensi pengguna media sosial dengan membaca pola penggunaan, pola pencarian, serta pola engagement yang dibentuk oleh pengguna media sosial melalui platform media sosial yang dimiliki dan dikelolanya. Tidak jarang pengguna media sosial mengidentifikasi brand tertentu sebagai preferensinya.

Brand yang telah sustainable, dalam penelitian ini adalah Danone AQUA, tidak lagi optimal memanfaatkan kanal-kanal konvensional yang sifat interaksinya cenderung satu arah, melainkan bergerak di kanal-kanal digital yang memungkinkan interaksi dengan konsumen dalam level yang lebih personal (personalized interaction), yang terjadi secara dua arah imbal-balik, hal tersebut terbukti pada hasil riset yang dilakukan oleh Nielsen Ad Intellit tahun 2018 , menunjukkan iklan-iklan yang bersaing ketat dalam kategori functional beverages, coffee, dan indulgance beverages

12 Definisi chatbot oleh Technopedia - https://www.techopedia.com/definition/16366/chatterbot

13 Loc. cit.

14 Hasil riset Nielsen Ad Intel tahun 2018, tentang gross rating point iklan minuman ready to drink di televisi nasional, dijelaskan dengan diagram Beverages Share of Voice. (https:/www.techopedia.com/definition/16366/chatterbot) 
menduduki tiga peringkat teratas untuk gross rating point di televisi nasional, sementara mineral water cukup bertaham pada posisi keempat dengan besaran 19\% dari GRP share. Disinyalir oleh Nielsen, mineral water sebagai salah satu minuman $R T D$, merupakan basic necessities yang lebih dibutuhkan konsumen, dibandingkan dengan kategori minuman yang lain, karena tanpa sengaja, mineral water telah memiliki keunggulan sebagai basic necessities, dalam penelitian ini Danone AQUA, telah menduduki kategori top of mind dalam benak konsumen.

\section{BEVERAGE SHARE OF VOICE (GRP)}

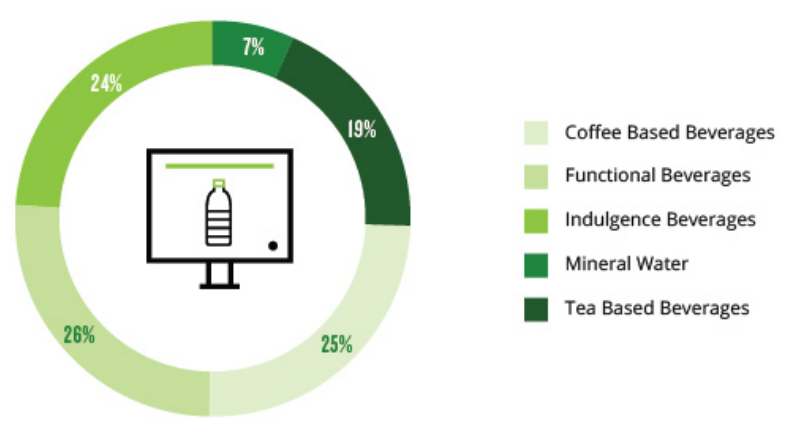

Danone AQUA menduduki posisi top of mind kategori air minum dalam kemasan, berdasarkan hasil survei Top of Brand Award tahun 2017 dan 2018, ${ }^{16}$ dalam benak konsumen AQUA diasosiakan dengan air minum dalam kemasan yang lazim dikonsumsi.

Grafik 3

Sumber: Top Brand Index dari Top Brand Award

AIR MINUM DALAM KEMASAN

\begin{tabular}{|l|l|l|}
\hline MEREK & TBI & TOP \\
\hline AQUA & $73.3 \%$ & TOP \\
\hline VIT & $6.1 \%$ & \\
\hline Club & $4.5 \%$ & \\
\hline Ades & $4.1 \%$ & \\
\hline 2 Tang & $1.8 \%$ & \\
\hline
\end{tabular}

AIR MINUM DALAM KEMASAN

\begin{tabular}{|l|l|l|}
\hline MEREK & TBI & TOP \\
\hline AQUA & $63.9 \%$ & TOP \\
\hline Ades & $7.6 \%$ & \\
\hline Club & $3.4 \%$ & \\
\hline 2 Tang & $3.2 \%$ & \\
\hline Cleo & $2.7 \%$ & \\
\hline
\end{tabular}

Bagi sebagian brand, tahun 2017 merupakan titik jenuh kampanye digital. Perlu ada inovasi baru supaya target market tidak bosan dengan bentuk kampanye digital. Brand tidak bisa lagi mengejar impresi (impression), yang dipahami sebagai jumlah terpaan pesan terhadap audiens, dengan mengandalkan postingan di media sosial lagi, namun harus bisa mendapatkan perhatian dan engagement dari pengguna media sosial. AQUA menyadari hal ini sehingga menginginkan kampanye digital yang berbeda untuk mengawali tahun 2017.

15 Nielsen Ad Intel, loc. cit.

16 Hasil survei Top Brand Award berdasarkan Top Brand Index AQUA, tahun 2017 dan 2018. - http://www.topbrand-award. com/top-brand-survey/survey-result/ 
AQUA telah menjadi top-of-mind product air mineral di Indonesia. AQUA juga aktif melakukan promosi untuk terus menjaga posisi ini di masyarakat. Promosi yang dilakukan AQUA tidak sebatas menggunakan metode konvensional, namun juga menggunakan kampanye digital. AQUA telah memiliki aset digital di Twitter ${ }^{17}$ dan Facebook ${ }^{18}$ serta aktif $^{2}$ menggunakan tagar \#AdaAQUA yang dijadikan landasan strategi integrated marketing.

Chatbot pada tahun 2017 masih jarang terdengar di Indonesia. GDILab ${ }^{19}$ sebagai partner Twitter wilayah Asia Tenggara memiliki kemampuan untuk membuat social media chatbot yang bekerja pada platform Twitter dan Facebook. Keunggulan dari social media chatbot adalah target market tidak perlu meng-install aplikasi tambahan di perangkat smartphone/komputer mereka, namun cukup menggunakan aplikasi Twitter atau Facebook dan nantinya chatbot yang akan menghampiri mereka.

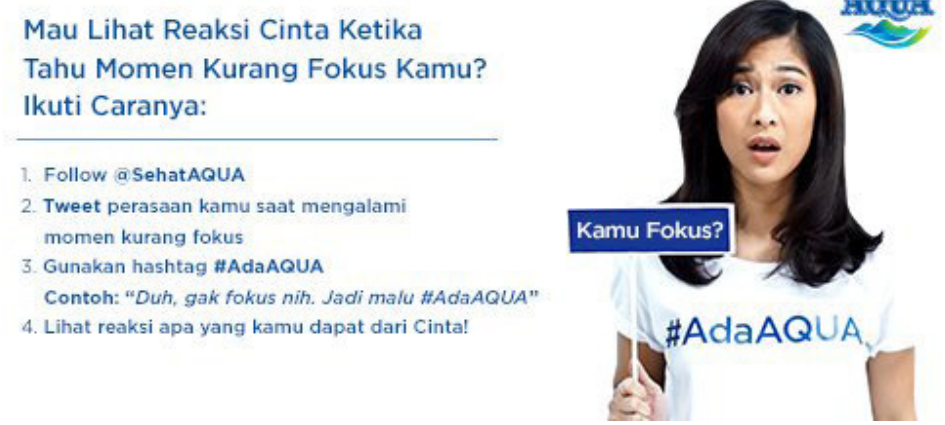

Gambar1Postingan tweet @sehatAQUA untukmengajak mencoba autoresponder.

Pada tahap pertama, GDILab membuatkan autoresponder yang berjalan pada Twitter menggunakan tagar

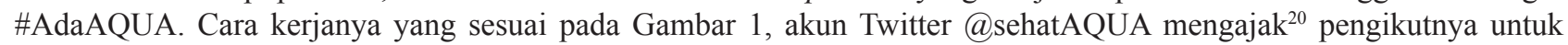
melakukan tweet menggunakan tagar \#AdaAQUA, nantinya setiap tweet tersebut akan mendapatkan balasan dari akun Twitter@sehatAQUA dengan pesan yang telah disesuaikan. Pada saat itu respon dari pengguna pengguna sangat baik, dimulai dari ratusan tweet per hari yang direspon, hingga akhirnya mencapai ribuan tweet per hari setelah viral karena pada balasan tweet tersebut melampirkan gambar Dian Sastro.

Pada tahap pertama ini, tujuan yang diharapkan adalah impresi dari pengikut akun media sosial AQUA di Twitter, untuk mengetahui bahwa AQUA memiliki chatbot yang dapat berkomunikasi secara cepat. Hasil yang diperoleh melebihi ekspetasi awal, karena pada saat itu chatbot di media sosial belum banyak digunakan pada kampanye digital di Indonesia, sehingga pengguna Twitter dengan cepat memanfaatkan autoresponder \#AdaAQUA untuk berbagai hal. Selain itu pada tahap pertama ini peneliti mendapatkan temuan bahwa platform media sosial cukup fleksibel untuk dijadikan media kampanye digital dengan memanfaatkan fitur developer ${ }^{21}$ yang disediakan oleh platform media sosial.

Pada tahap kedua, AQUA mengharapkan peran chatbot dapat membantu meningkatkan penjualan produk AQUA pada tingkat retail. Hal ini dianggap wajar karena chatbot AQUA sudah mendapatkan perhatian dari pengguna media sosial. Berbekal hasil yang didapatkan pada tahap pertama, maka perlu ada game plan baru supaya pengguna media sosial tidak merasa terjebak dengan chatbot yang telah diluncurkan sebelumnya.

Strategi yang disusun melibatkan beberapa stakeholder untuk membuat game plan berjalan dengan baik. Stakeholder yang berkolaborasi antara lain AQUA sebagai penyedia produk; Alfamart dan Indomaret sebagai sektor retail; Go-Pay dari Go-Jek sebagai gimmick; Twitter dan Facebook sebagai platform social media chatbot; dan GDILab sebagai pihak developer.

Go-Jek sebagai perusahaan startup digital Indonesia yang bergerak di bidang layanan transportasi online mulai melebarkan layanannya ke pembayaran online. Go-Pay adalah layanan yang bisa digunakan untuk membayar ke semua layanan Go-Jek secara non-tunai. Awal tahun 2017 penggunaan layanan Go-Pay masih belum sesuai harapan karena pelanggan Go-Jek lebih memilih membayar menggunakan uang tunai. Hal ini wajar sebab saat itu metode pembayaran non-tunai (cashless) masih belum familiar, sehingga kepercayaan terhadap layanan Go-Pay di masyarakat masih rendah. Maka pada kolaborasi ini, Go-Jek akan memberikan gimmick marketing berupa Go-Pay senilai Rp10.000,00 untuk setiap kode voucher yang berhasil ditukarkan.

Adapun tahapan customer engagement yang terjalin antara konsumen dengan produsen ( $\mathrm{brand} /$ korporasi) sebagai bagian dari kampanye \#AdaAQUA, yang melibatkan berbagai pelaku industri, dapat dijelaskan dalam kronologi proses

17 Akun Twitter@sehatAQUA - https://twitter.com/sehatAQUA

18 Facebook Page Sehat AQUA - https://www.facebook.com/SehatAQUA/

19 Official Website GDILab - https://www.gdilab.com

$20 \mathrm{https}: / /$ twitter.com/sehatAQUA/status/711456793961046016

21 Kanal Twitter Developer - https://developer.twitter.com/ 
sebagai berikut:

1. AQUA membuat promosi konvensional dan kampanye digital yang menginformasikan terdapat cashback berupa saldo Go-Pay setiap pembelian 4 botol AQUA 600ml di Indomaret dan Alfamart.

2. Pembeli yang membeli 4 botol AQUA $600 \mathrm{ml}$ mendapatkan kode voucher unik dari kasir setelah menyelesaikan transaksi.

3. Pembeli menukarkan kode voucher tersebut dengan cara melakukan DM (Direct Messaging) pada akun Twitter@sehatAQUA atau melalui FB Messenger di Fanpage SehatAQUA.

4. GDILab membangun chatbot yang bisa melakukan validasi kode.

5. Apabila kode voucher dinyatakan valid dan belum pernah digunakan, maka chatbot akan memberikan respon balasan berupa kode voucher Go-Pay.

6. Apabila kode voucher gagal divalidasi, maka chatbot akan memberikan respon pesan kesalahan kepada pembeli.

7. Pembeli yang mendapatkan kode voucher Go-Pay dari chatbot bisa melakukan voucher redeem pada aplikasi Go-Jek untuk mendapatkan saldo sebesar Rp10.000,00 (sepuluh ribu rupiah).

Merujuk pada rangkaian proses collaborated engagement marketing yang diuraikan di atas, maka dapat dipahami bahwa media sosial juga dapat berperan sebagai auto responder, yang diimplementasikan melalui chatbot yang juga melayani fungsi sebagai fitur yang mampu mengintegrasikan informasi untuk keperluan produsen dan konsumen consumer goods, yang menguntungkan kedua belah pihak, sebagaimana ditunjukkan oleh gambar 3 berikut pada tampilan layar fitur direct message bagian dari Twitter, dan gambar 4 yang merupakan tampilan dari fitur messenger pada Facebook.

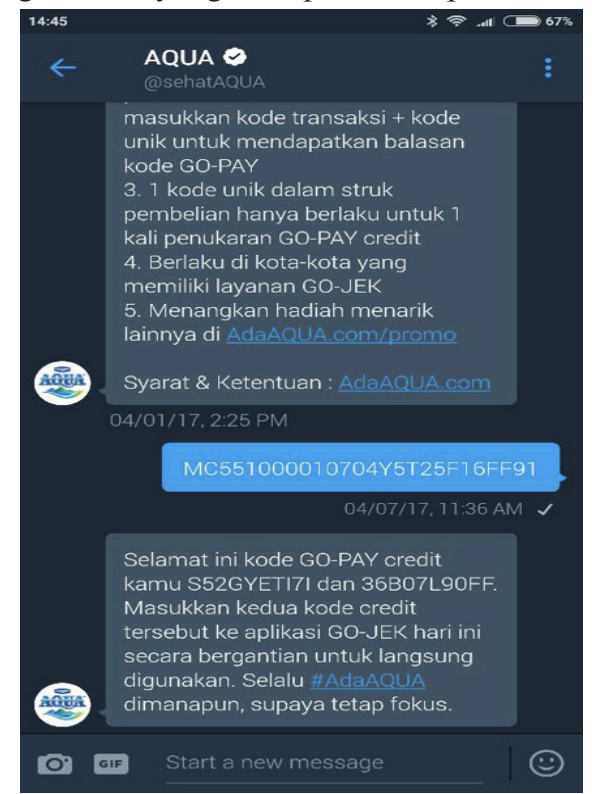

Gambar 3 Tampilan Twitter DM ke @sehatAQUA untuk proses validasi voucher.

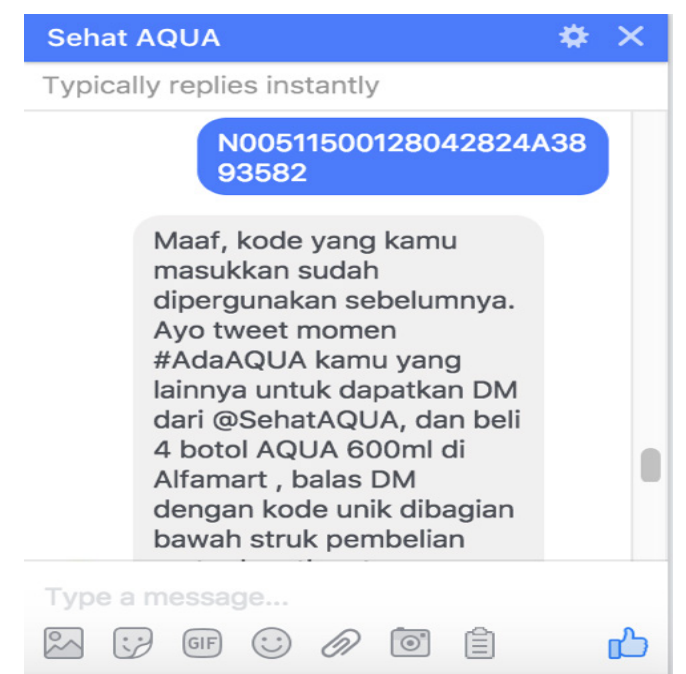

Gambar 4 Tampilan FB Messenger pada Fanpage Sehat AQUA saat proses validasi voucher. 
Implementasi tahap 2 pada periode Februari - April 2017 menghasilkan 54.719 postingan di Twitter menggunakan tagar \#AdaAQUA. Indomaret melaporkan telah menciptakan 420.000 voucher dari setiap pembelian 4 botol AQUA, Alfamart tidak bersedia memberikan data jumlah voucher yang diciptakan, dan jumlah voucher Go-Pay di-redeem sejumlah 21.917 dengan nilai Rp10.000,00 (sepuluh ribu rupiah) untuk setiap vouchernya.

Customer engagement telah mengalami perluasan makna seiring dengan semakin banyaknya penelitian yang membahas tentang customer engagement itu sendiri. Penelitian ini sinergis dengan pemahaman tentang customer engagement dimana proses customer engagement tersebut melayani beberapa fungsi pemasaran, berupa pemenuhan akuisisi, ekspansi, dan retensi pelanggan, serta mewujudkan inovasi produk (Harmeling et al., 2017).

Penelitian ini menjelaskan fungsi pemasaran yang dipenuhi dengan adanya customer engagement tersebut adalah fungsi akuisisi, ekspansi, dan retensi konsumen, sekaligus fungsi inovasi produk. Tipologi customer engagement dalam penelitian ini akan dijelaskan sebagai bagian dari praktek collaborated engagement marketing yang dilakukan oleh Danone AQUA melalui Twitter, bekerjasama dengan Go-Jek dan Alfamart, dengan mengadopsi model yang dikemukakan oleh (Harmeling et al., 2017) yang mengacu pada pemahaman tentang customer engagement oleh (Hollebeek, 2011).

\begin{tabular}{|l|l|}
\hline \multicolumn{1}{|c|}{ Tipologi } & \multicolumn{1}{c|}{ Contoh penerapan } \\
\hline Customer resources integration & $\begin{array}{l}\text { Konsumen memanfaatkan Twitter, untuk melakukan voucher } \\
\text { redeem melalui fitur Direct Message (DM), yang direspon oleh } \\
\text { social media chatbot. }\end{array}$ \\
\hline Customer knowledge & $\begin{array}{l}\text { Konsumen yang telah melakukan voucher redeem melalui fitur } \\
\text { DM Twitter, akan membagikan pengalaman ke jaringan (network) } \\
\text { yang dimilikinya melalui timeline, dengan menuliskan } \text { tweet yang } \\
\text { menggunakan \#AdaAQUA. }\end{array}$ \\
\hline Customer learning & $\begin{array}{l}\text { Konsumen akan memahami social media dalam konteks yang } \\
\text { berbeda, karena telah mengalami interaksi dengan entitas } \\
\text { percakapan buatan (ACE) berupa chatbot, sekaligus mendapatkan } \\
\text { benefit dari penggunaan social media. }\end{array}$ \\
\hline
\end{tabular}

\section{KESIMPULAN}

Fenomena social media chatbot, telah mengindikasikan dimulainya era baru dalam marketing, tidak lagi sebatas integrated marketing, yang bersinergi dengan integrated marketing communication, maupun omni-channel marketing, yang memungkinkan pengguna internet sekaligus konsumen untuk memanfaatkan beberapa platform (social media) dan teknologi internet untuk menginisiasi aktivitas konsumsi produk maupun servis, dari industri terkait, namun mewujudkan adanya collaborated engagement marketing, hasil kerjasama antara tiga korporasi berbeda. Penelitian lain yang bisa dikembangkan, dapat membahas tentang customer engagement yang diproyeksikan untuk secara langsung membantu meningkatkan sales, atau penelitian membahas tentang personalized engagement yang memanfaatkan social media chatbot untuk memberikan rekomendasi kepada pengguna social media.

\section{DAFTAR PUSTAKA}

Amalia, A., \& Suprayogi, M. S. (2016). Marking Social Issue On Social Media: Case Study Of Social Media's Trending Topics Representing Urban Issue In Yogyakarta On Twitter. In International Conference on Social Politics ( $\mathrm{p}$. 913). Yogyakarta: Jusuf Kalla School of Government (JKSG).

APJII. (2018). Hasil Survei Penetrasi dan Perilaku Pengguna Internet 2017 APJII. Retrieved January 24, 2019, from https://kominfo.go.id/content/detail/12638/hasil-survei-penetrasi-dan-perilaku-pengguna-internet-2017-apjii/0/ download

Atsmon, Y., \& Magni, M. (2016). Chinese consumers: Revisiting our predictions | McKinsey. Retrieved January 24, 2019, from https://www.mckinsey.com/industries/retail/our-insights/chinese-consumers-revisiting-our-predictions

Choudhury, N. (2014). World Wide Web and Its Journey from Web 1.0 to Web 4.0. BMC Bioinformatics. https://doi. org/10.1186/1471-2105-9-82

Harmeling, C. M., Moffett, J. W., Arnold, M. J., \& Carlson, B. D. (2017). Toward a theory of customer engagement marketing. Journal of the Academy of Marketing Science, 45(3), 312-335. https://doi.org/10.1007/s11747-0160509-2

Hollebeek, L. (2011). Exploring customer brand engagement: definition and themes. Journal of Strategic Marketing, 19(7), 555-573. https://doi.org/10.1080/0965254X.2011.599493

Lister, M., Dovey, J., Giddings, S., Grant, I., \& Kelly, K. (2003). New media: A critical introduction. Social Sciences. 
https://doi.org/10.1177/026858090702200234

Mangold, W. G., \& Faulds, D. J. (2009). Social media: The new hybrid element of the promotion mix. Business Horizons, 52(4), 357-365. https://doi.org/10.1016/J.BUSHOR.2009.03.002

TheJakartaPost. (2018). Indonesia to see more fragmented competition in FMCG: Euromonitor - Inforial - The Jakarta Post. Retrieved January 24, 2019, from https://www.thejakartapost.com/adv/2018/09/27/indonesia-to-see-morefragmented-competition-in-fmcg-euromonitor.html

Xu, F., Weber, J., \& Buhalis, D. (2013). Gamification in tourism. In Information and Communication Technologies in Tourism 2014 (pp. 525-537). Springer.

Zipser, D., Gong, F., \& Chen, Y. (2016). Here comes the modern Chinese consumer | McKinsey. Retrieved January 24, 2019, from https://www.mckinsey.com/industries/retail/our-insights/here-comes-the-modern-chinese-consumer 